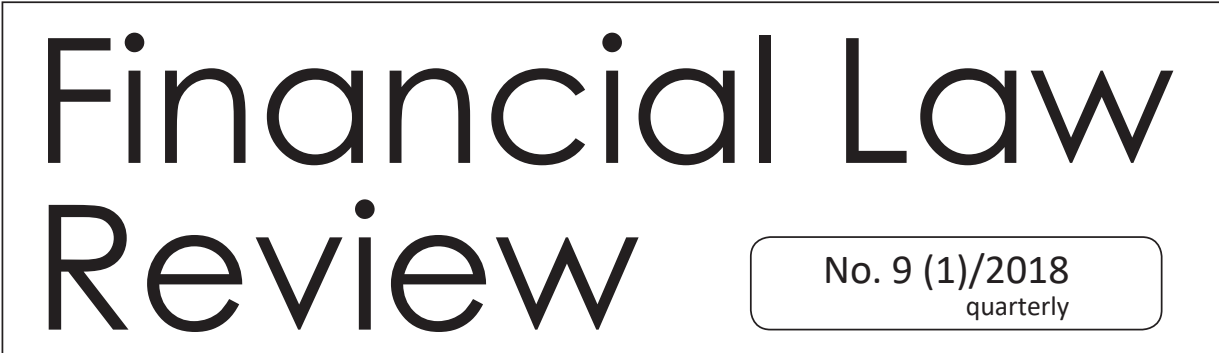

UNIVERSITY OF GDAŃSK • MASARYK UNIVERSITY • PAVEL JOZEF ŠAFÁRIK UNIVERSITY • UNIVERSITY OF VORONEZH http://www.ejournals.eu $\bullet$ http://czasopisma.bg.ug.edu.pl

\title{
LEGAL ASPECTS OF SELECTED MODERN METHODS OF PAYMENT ${ }^{1}$ \\ MACIEJ MIKLIŃSKI*
}

\begin{abstract}
The following article presents reflections on modern methods of payment in light of the changing essence of money and its function. In modern times the ambiguous concept of money and the method of its issue have constitutional relevance in view of the fact that money is not backed by bullion any longer. Meanwhile, in addition to money in its pure form, there are other methods of payment arousing discussion such as: monetary means, electronic money or virtual currencies. This raises questions as to the acceptable forms of payment and the legal consequences of using means of payment other than money in the strict sense. This paper presents selected items from among the complex legal issues concerning money and payment in order to outline the typical ways to resolve legal problems of using the modern methods of payment.
\end{abstract}

\section{Key words}

Payment.

JEL Classification: https://www.aeaweb.org/jel/guide/jel.php

The article is a reprint of the article originally published in Studies and Papers of the Institute of Maritime Transport and Seaborne Trade no. 13 (2016).

* Mgr, barrister, Department of Financial Law, Faculty of Law and Administration, University of Gdansk, Poland, e-mail: mmiklinski@prawo.ug.edu.pl 


\section{Introduction}

The present times, along with the progress of civilization, bring new ways of making payment, slowly replacing money with its traditional definition. This happens, inter alia, due to the acceptance of a variety of instruments in trading which are not money, and which, owing to the facilitation of use, and gaining social acceptance, become a modern form of intermediate means in the trade exchange. Despite the constitutional nature of money, other means of payment and methods of releasing from financial obligations than the payment with money are promoted. This raises questions about the legal aspects of using means of payment in trading other than money.

\section{Historical outline}

With the development of civilization, with the emergence of new needs, with the growing range of trade exchange, societies managed to find appropriate means intermediating in such exchange. Initially these were practical and then mostly unique and durable items used to release from obligations and keep the value for years.

The Egyptian civilization used silver or bronze in this regard (Kemp, 2009: 368). Also the monuments of law showing the level of the Babylonian civilization, such as the Code of Hammurabi, indicate the use of cereals and silver as the legally defined means to release from obligations, including payment of compensation (Skeczkowski, 1995: 33; Jursa, 2002:34).

Both the experience gained and the durability, divisibility, small size with some substantial value at the same time, as well as acceptance on a considerable territorial range were the reasons why it was mainly gold and silver that remained as the intermediate element in the exchange, the so called commodity money. According to the current knowledge the first coins started to be minted from a natural alloy of gold and silver called electrum in the town of Sardeis about the $7^{\text {th }}$ century BC (Merkelbach, 1996:15). Their appearance initially minimised the risk associated with the purity and mass of the metal, although in the subsequent centuries the turbulence of war and the needs of rulers provided many examples of how the value of coins was depreciated by issuers (Mrozek, 1978:12).

For hundreds of years, it was a natural fact for subsequent generations that the possession of a coin, and in particular, the metal of which it was made, gave the sense of possession of value and security. In addition to the possibility of using the coin, 
the ease of hiding, transferring, using it to pay obligations without the participation of intermediaries, made it possible to keep the value and the purchasing power for generations. Due to the metal of which the coin was made, the function and possibility of payment, and thus the release from obligations lasted for centuries, in principle, regardless of the venue where the transaction was made.

The second important step on the way to the present day was the paper money which appeared for the first time in the $10^{\text {th }}$ century in China, with a three-year term of validity and which was theoretically backed by silver (Morawski, 2002: $55,56)$. In Europe it was the Swedes who were the first to get familiar with paper money as they, not having wide access to deposits of gold, but having rich deposits of copper, began to mint copper coins called plåtmynts. To retain a proper value the coins were large in size and weight, for example a 10-thaler coin weighed $20 \mathrm{~kg}$ (Morawski, 2002: 61), and therefore it was troublesome to use them from a practical point of view. To facilitate the exchange of such plåtmynts, paper bearer documents were issued and the holder of such a document could release himself from an obligation by handing the other party a bearer document or exchange it for a plàtmynt of a marked value. In practice, this solution gained social acceptance, and a piece of paper began to serve as a means of releasing from obligations. The necessary intermediary in the form of a bank also appeared to watch over the real value locked in the vault.

This simple and practical solution was used both by commercial banks and the emerging central banks, taking gold and silver to their vaults and issuing bearer bank notes (banknotes). However, the issue of bearer banknotes corresponding to the actually acquired precious metals was not all. The idea was used in a creative way, banknotes not backed by bullion started to be issued, it having been observed that a request for exchanging banknotes for bullion was not frequent statistically and the issue of a banknote and lending it earned interest.

In this way societies were made familiar with paper money by accepting the fact that the release from obligations may be effected by handing a banknote. With the passage of years, societies were deprived of the right to exchange banknotes for bullion, leaving this right to central banks. Eventually, also central banks broke the connection of the issued currency with gold or silver. Banknotes and coins not backed by gold or silver have been left in the market.

At the present time, one can get the impression that the situation is even more complex by reason of the promoted money substitutes. 


\section{Money nowadays}

As a result of the outlined transformations, the contemporary money has been deprived of the natural backing by bullion, hence, its stability has become a system problem of the state (Balcerowicz, 2006:9). The functioning of the so called fiduciary money, which draws its power from the trust in the issuing state, requires constitutional security, due to the ease with which it can lose its value, and therefore the value of the work of whole generations contained therein.

For these reasons the issue of money and protection of its value have acquired a constitutional value. Pursuant to Art. 227 para. 1 of the Constitution of Poland: The central bank of the state is the National Bank of Poland. It shall have the exclusive right to issue money as well as to formulate and implement the monetary policy. The National Bank of Poland shall be responsible for the value of the Polish currency. As a result, the issue of money is strictly controlled. The constitutional solutions are complemented by the Act on the National Bank of Poland providing in Art. 31 that: The legal tender of the Republic of Poland shall be banknotes and coins denominated in zloty and grosz. In addition, in Art. 32 of the quoted Act it is stipulated that: The banknotes and coins issued by the National Bank of Poland shall be legal tender on the territory of the Republic of Poland. As a result of the adopted solutions money is a concept strongly rooted in the system solutions, controlled in a very precise way and, moreover, extremely heavily protected. On the one hand, its value is under the care of the constitutional authority represented by the National Bank of Poland whose independence includes but is not limited to financial, functional and institutional independence (Gliniecka, 2004), (judgment of the Constitutional Court: K 26/03). Furthermore, from the point of view of the material substrate, such security is ensured by Art. 310 para. 1 of the Penal Code providing that forging or altering the Polish currency is a crime punishable by imprisonment from 5 to 25 years. The issue of the state's own currency is also a manifestation of the state sovereignty of the Republic of Poland. In the contemporary times, financial sovereignty is not only the most important manifestation of sovereignty, but even a separate area which expresses the identity of the Polish State (Dębowska-Romanowska, 2010:21).

\section{Essence of payment vs. methods of payment}

In the case of a monetary obligation the subject of payment are not items of money marked individually or by type, but a certain economic value contained in the form of a sum of money expressed in monetary units (Czachórski, 1994: 
59). As a result, the release from a financial obligation is effected, as to the principle, by handing an appropriate quantity and value of legal tenders.

Nevertheless, the indicated legal solutions represent only the traditional way of release from financial obligations as a result of payment of debt in money. Meanwhile, the expansion of electronic media, the Internet, banking, clearing and settlement methods has, on the one hand, facilitated, and on the other hand, made the society familiar with cashless methods of settlements. Only few people consider and can see the essential difference between payment by cash and a cashless payment by, for example, a wire transfer. For the majority these transactions are identical. However, insomuch as they lead to similar effects in normal conditions of trading, the risks and legal mechanisms related to them which form and accompany them are totally different.

To some extent payment in cash becomes even excluded by the legislator, as is the case with payment of taxes by entrepreneurs. The Tax Ordinance Act of 29 August 1997 stipulates the basic obligation that taxes should be paid by entrepreneurs by wire transfer ${ }^{2}$. Hence, the question arises whether a wire transfer is payment in money. The answer to this question in academic studies is disputable, the author of this study adheres to the opinion which gives a negative answer to this question. The questions arising in connection with the foregoing are: What is a wire transfer? And in a broader sense: What are monetary means held on bank accounts? And what is their essence? They are not money in the strict sense of the word, since money, as has been indicated before, is coins and banknotes issued by the National Bank of Poland. To understand the difference, one should see what a bank account is and what the monetary means held in the bank account are. A bank account agreement is governed by, inter alia, Art. 725 of the Civil Code where it is stipulated that: under the bank account agreement the bank undertakes to hold the account holder's monetary means for a fixed or indefinite period of time, and, if the agreement so provides, to make financial settlements upon the account holder's instruction. Furthermore, pursuant to Art. 726 of the Civil Code: the Bank may temporarily use the free monetary means held on the bank account with the obligation to return them, in whole or in part, upon each demand, unless the agreement stipulates that the obligation to return the monetary means depends on the notice of termination.

The Tax Ordinance in Art. 61, para. 1 provides that payment of taxes by taxpayers conducting business activities and obligated to maintain a book of accounts or a revenue and expense ledger in made by wire transfer. 
This means that the bank account holder is entitled against the Bank only to a claim for a return of money in cash and possibly for making settlements. This is substantiated not only by interpretation of the quoted provisions but also by the decisions of the Supreme Court which has decreed, inter alia, that upon the moment of depositing money at the bank the holder loses possession thereof in favour of the Bank, and acquires a claim for a refund of the same value in cash or in a cashless form in favour of himself or in favour of a third party (Supreme Court: V CSK 163/10; also VI KO 23/62, OSNKW, 1963, No. 2, item 21; also V CK 233/03; also V CSK 255/07).

The legal aspect of the release from financial obligations by a wire transfer is debatable, nonetheless, the due attention has not been given thereto in the literature devoted to this subject. The question arises on the basis of what legal structure payment is made, since it is not money that causes a financial obligation to expire. In particular, the constructs of assignment of claims, assumption of debt or a specific form of settlements are considered here (Chłopecki et al, 1996:6-7; Socha, 2000: 72-73). The differences are essential. Most of all, there is no doubt that in the case of a wire transfer we are not dealing with a monetary payment in the strict sense of the term. Money, legal tenders, definitely are not present in this transaction. Therefore, it is possible to consider a concept that a wire transfer leads to the assignment of the debtor's claim (a monetary claim) against his bank to the creditor (of the monetary claim). In this situation, the monetary claim is satisfied by a non-monetary payment and the grounds should be sought in principle either in Art. 453 of the Civil Code (datio in solutum), i.e. with the creditor's approval a different payment may be effected to become released from the obligation, or the argumentation should be accepted that in consequence of the established custom (Art. 56 of the Civil Code) the fulfilled payment should be considered as consistent with the custom (Chłopecki et al, 1996:7). If both the creditor and the debtor have accounts with the same bank, the debtor's account is debited and the creditor's account is credited. The matter becomes more complicated when accounts are held at two different banks, in such event, it is not only the two banks, but also a settlement institution that participate in the transaction. On the other hand, if the debt assumption concept is adopted, there is a situation where the party assuming the debt, i.e. the creditor's bank, would assume a debt that would become the bank's own obligation for the same amount of payment, and the former debtor would be released from the debt (Chłopecki et al, 1996:9). This concept is more complex in view of the fact that the debt assumption contract may be concluded between the creditor and the debt assumer with 
the debtor's consent, or with the debt assumer and the debtor with the creditor's consent. Still another concept seems to arise from the position of the Supreme Court that in its judgment of 18 February 2004, V CK 233/03 has concluded, inter alia, that the claim of the person to whose account monetary means have been transferred originates as a result of the account holder's act of instructing the monetary means to be transferred, however, it is not a result of the assignment of claims within the meaning of Art. 509 of the Civil Code. From the point of view of the bank account agreement between the beneficiary of the settlement and "his" bank the settlement instruction is a spontaneous event, independent of the beneficiary's will that creates the subject of the obligation between "his" bank and himself. The beneficiary's claim against the bank arising at the moment of crediting the beneficiary's account is a right related to his bank account agreement and subject to his disposal.

Nevertheless, the most important issue is the answer to the question whether the payment made by a wire transfer is fulfilled in accordance with the contents of the financial obligation. On principle, it is only payment by money that causes a monetary obligation to expire, however, as a result of the creditor's consent, or the existence of a custom in this respect, it is considered that payment by wire transfer releases from the financial obligation.

From ja practical point of view, payment by wire transfer is treated as if it were the same as payment by cash and it does not lead to any significant problems, when the banking system retains its stability. As long as there are no violent events or bankruptcy in this system, except for the obvious issues such as handing a legal tender or the lack thereof, it is in fact difficult to distinguish by what cash money differs from the monetary means also called the bank money and constituting a certain kind of a claim only.

It cannot be forgotten that while traditional banks used to be synonymous with security and sayings such as "as safe as in a bank" carried the belief about the security of the monetary means entrusted to the bank, nowadays the very definition of a bank indicates the risk to which the funds entrusted to the bank are exposed ${ }^{3}$. Inasmuch as the care of the quantity and power of money is the responsibility of the National Bank of Poland, the National Bank has nonetheless increasingly lesser influence on the implementation of the purpose of its tasks, when

Pursuant to Art. 2 of the Bank Law Act of 29 August 1997, Dziennik Ustaw of 2015, item 128 (as amended) it is provided that $A$ bank is a legal entity established in accordance with the provisions of the acts, acting on the basis of permits to perform banking activities imposing risk on the entrusted funds under any title of refunding. 
other means of payment are used, with the approval of politicians, over which the National Bank of Poland does not have efficient control any longer.

A principal issue in this regard is the use of foreign means of payment in transactions in Poland. The relaxation of the foreign exchange regulations and amendments to the Civil Code have led to the possibility of incurring obligations in foreign currencies for purposes not related to foreign trading but directly to the domestic market. The national currency principle according to which financial obligations on the territory of the Republic of Poland may be denominated only in the Polish currency has been abandoned by the Act of 23 October 2008 to amend the Civil Code and the Foreign Exchange Act which amended both Article 9 subpara. 15 of the Foreign Exchange Act and Article $358^{4}$ of the Civil Code. This was done despite the reservations of the National Bank of Poland. The National Bank of Poland also noted that the proposed solution may pose a risk of weakening the efficiency of the transmission mechanism of monetary impulses of the National Bank of Poland to the economy, by lowering short-and medium-term impact of the Central Bank on the real economy and inflation ${ }^{5}$. This has led to a situation in which obligations in the territory of Poland in connection with making payments in the territory of Poland arise and are performed using a foreign currency. As a result, the element of sovereignty of the state, which is the state's own currency, has been significantly weakened, as it is possible to bypass its power by way of a consensus between the interested parties.

In consequence, legislative changes not only operate in a way weakening the constitutional position of the authority which the National Bank of Poland is, but also lead to the emergence of solutions which allow a wide circle of citizens as well as local government bodies to incur obligations in foreign currencies for the purposes related to domestic transactions. A rapid fluctuation of the exchange rate

4 As a result, the following provision was deleted from the Foreign Exchange Law stipulating that restrictions applied to "entering into contracts and conducting other legal transactions causing or likely to cause settlements in foreign currencies in Poland, and also making such settlements in Poland except in cases where such activities are carried out in foreign exchange trading permitted by the Act or by a foreign exchange permit: a) with foreign countries, as referred to in Art. 2 para. 1. subpara. 17 point $a, b$ ) between non-residents, $c$ ) between residents who are natural persons, in terms unrelated to economic activity." Moreover, the existing provision of Art. 358 of the Civil Code reading: "Subject to the exceptions stipulated in the Act, financial obligations in the territory of the Republic of Poland may be denominated only in the Polish currency." was deleted.

5 Grounds for the draft act to amend the Civil Code and the Foreign Exchange Act http://orka. sejm.gov.pl/ Druki6ka.nsf/0/1C0ED 9063FC9F122C1257442 002C0434/\$file/470.pdf, (last visited: 5 February 2016). 
of the Polish zloty with respect to other currencies can destabilize the country internally, which is evidenced, for example, by the current problems experienced by people having loans denominated or indexed in foreign currencies. The comments regarding the problem of monetary means in bank accounts should be applied to foreign monetary means respectively. However, for the sake of clarity, it should be noted that payment by foreign money is payment by money in its proper sense.

Another method of payment is the use of electronic money which is issued in accordance with the Payment Services Act of 19 August 2011 and which is a monetary value stored electronically, including magnetic devices, issued, with the obligation to redeem, in order to make payment transactions accepted by entities other than the issuer of the electronic money only. This type of payment has not gained any wide popularity so far and the number of transactions made with it is not significant. Nevertheless, payment with this method also presents a challenge for lawyers seeking answers to the question what causes a financial obligation to expire, as it is not money within the constitutional meaning but a claim for return of money hidden in the electronic form.

Financial obligations are nowadays satisfied commonly through payments made with credit cards. They are, as a rule, means of access to bank accounts enabling, inter alia, card issuers, banks, merchants and bank account holders to conduct transactions in a complex contractual system the subject matter of which again is not money but claims called monetary means.

As a result of practical facilitation connected with card payments, but also payments using other devices such as mobile phones, opinions can be heard on a mass scale claiming that money should not have a material form that it should disappear and that it should be replaced by monetary means, i.e. money in the economic meaning, from the legal point of view being only a claim for the return of cash.

Another example of departing from the use of money in its legal sense are virtual currencies, including the most popular currency - Bitcoin. Similarly to the commodity money centuries ago, the primary feature of Bitcoin is that it is created outside the state or central banks system. Its existence and value which it carries are created outside the system of central banks and its power comes from its common acceptance in the world. Hence, just like kauri shells in Africa or axes in pre-Celtic Brittany were methods of payment centuries ago, IT records gain this power nowadays by way of agreement, with this difference that they do not have a material 
form and moreover, their transfer from one place in the world to another takes only minutes. There would be nothing surprising in it if the scope of use included only groups of collectors, however, their use begins to reach the practice of everyday life. Nowadays in Poland it is possible not only to recharge a telephone card with bitcoins but to pay, e.g., for medical services as well. In this regard changes occur rapidly and the legal aspect of payments made by a wide range of consumers to businesses using virtual currencies is reduced to the fact that there is an intermediary institution participating in the payment for goods or services. It buys virtual currency units from the party obliged to pay the price and pays out monetary means to the supplier of service who is waiting for payment. The actual payment is therefore made in money or in monetary means, which from the civil law, tax law and accounting law perspective is a substantial facilitation. Virtual currencies are the subject of consideration whether they should be treated as a means of payment or an equivalent of payment (Zacharzewski, 2015:187).

\section{Conclusion}

Similarly to how our ancestors were made familiar with the paper money gradually depriving it of redeemability in bullion, attempts are made to convince the contemporaries to use electronic means of redemption of obligations indicating that money in the constitutional sense, having the form of coins and banknotes issued by the constitutional authority, is an anachronism. The phenomenon of using a method of satisfying financial obligations other than with money seems to develop in two main directions. The first is the increased role of banks and monetary means deposited on bank accounts with simultaneous promotion of electronic access thereto both via the Internet and through credit cards or payment devices operating in a similar way. The key here is the state's supervision over banks, as well as ensuring the security of the system to maintain the value of money and to convert money into monetary means and vice versa. The other direction develops outside of the state system and includes the use of complex and unique IT instruments whereto the value of a means intermediating in the exchange is started to be assigned. Such monetary means are issued and transferred, redeeming cash obligations beyond the control of states, they are transmitted electronically, over their borders and constitute a type of modern commodity money that is characterized by wide acceptance, independence from the state governments and the banking system. 
An effect of the widespread use of the term "money" in the economic sense is that it begins to lose its sharp and clear legal attributes, leading to the blurring of the concept of "payment". Payment starts to be understood in more general terms (Dybowski et al, 2013) and not as making a strictly monetary payment. This leads to the conclusion that we have been witnessing and have become participants of another key transformation of the form and concept of money and payment.

\section{References}

Balcerowicz, L.: Praworządność, pieniądz i demokracja (Lawfulness, money and democracy), Nauka (Science) no. 4 (2006).

Bank Law Act of 29 August 1997, Journal of Laws of 2015 item 128 as amended.

Chłopecki, A. et al: Zagadnienia prawne rozliczeń bankowych (Legal Issues Relating To Bank Transactions), Glosa (Gloss) no. 11 (1996)

Czachórski, W.: Zobowiązania. Zarys wykładu (Obligations. An Outline of a Lecture), Warszawa: LexisNexis, 1994.

Dębowska-Romanowska, T.: Pojęcie i znaczenie konstytucjonalizacji ustroju i systemu finansowego państwa (The Notion and Meaning of the Constitutionalisation of the Political and Financial System of the Country), in: Konstytucyjne uwarunkowania tworzenia i stosowania prawa finansowego i podatkowego (Constiutional Conditioning of Creation and Application of the Financial and Tax Law), Lewkowicz, P. et al., eds., Białystok: Temida2, 2010.

Dybowski, T. et al: Prawo zobowiązań - część ogólna (The Lawe of Obligations - general part), in: Łętowska E. ed.: System Prawa Prywatnego (The System of the Private Law), Warszawa: C.H. Beck 2013.

Gliniecka, J.: System bankowy w regulacjach polskich i unijnych (The Banking System in the Polish and EU Regulations), Bydgoszcz-Gdańsk: Branta, 2004.

Grounds for the draft act to amend the Civil Code and the Foreign Exchange Act http:// orka.sejm.gov.pl/ Druki6ka.nsf/0/1C0ED 9063FC9F122C1257442002C0434 /\$file 1470.pdf (access: 5 February 2016).

Judgment of the Constitutional Court of 24 November 2003, K 26/03.

Jursa, M.: Prywatyzacja i zysk. Przedsiębiorcy a gospodarka instytucjonalna w Mezopotamii od 3 do 1 tysiąclecia przed Chrystusem (Privatization and profit. Entrepreneurs and the institutional economy in Mesopotamia from 3rd to 1st millenium Before Christ), Poznań: PTPN, 2002.

Kemp, B.: Starożytny Egipt anatomia cywilizacji (The Ancient Egipt, the anatom of civilization, Warsaw: Państwowy Instytut Wydawniczy, 2009.

Merkelbach R.: Znaczenie pieniądza dla dziejów grecko-rzymskiego świata (The meaning of the money for the history of the Greek-Roman World), translated from German into Polish by Włodzimierz Appel, Toruń: Uniwersytet Mikołaja Kopernika, 1996. 
Morawski W.: Zarys powszechnej historii pieniądza i bankowości (The Outline of the Common History of the Money and Banking), Warsaw: Wydawnictwo Trio, 2002.

Mrozek, S.: Dewaluacje pieniądza w starożytności grecko-rzymskiej (Devaluation of money in the ancient Greek-Roman times), Wrocław: Wydawnictwo Polskiej Akademii Nauk, 1978.

Skeczkowski, R.: Pomniki Prawa (The Monuments of Law), Koszalin: Bałtycka Wyższa Szkoła Humanistyczna, 1995.

Socha, A.: Bankowe rozliczenia pieniężne a świadczenia pieniężne (Bank Transactions and Monetary Benefits), Radca Prawny (Legal Councel) no. 2 (2000).

Supreme Court: V CSK 163/10.

Supreme Court: VI KO 23/62, OSNKW, 1963, No. 2, item 21.

Supreme Court: V CK 233/03, not published.

Supreme Court: V CSK 255/07, not published.

The Act No. 228, item 1506, to amend the Civil Code and the Foreign Exchange Act.

The Act on the National Bank of Poland of 29 August 1997, Journal of Laws of 2013 item 908 as amended.

The Act on The Payment Services of 19 August 2011, as amended.

The Civil Code Act of 23 April 1964, as amended.

The Constitution of Poland of 2 April 1997, as amended.

The Penal Code Act of 2016, as amended.

The Tax Ordinance Act of 29 August 1997, as amended.

Zacharzewski, K.: Praktyczne znaczenie bitcoina na wybranych obszarach prawa prywatnego (Practical meaning of bitcoin in relation to selected areas of the private law), Monitor Prawniczy (Law Monitor) no. 4 (2015). 